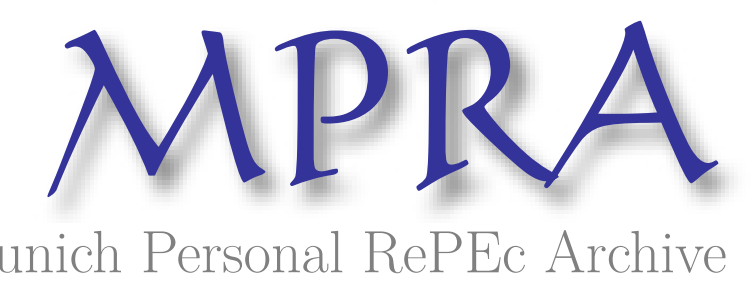

\title{
Foreign Subsidiary, Transfer Pricing and Tariffs
}

Kant, Chander

July 1988

Online at https://mpra.ub.uni-muenchen.de/91947/

MPRA Paper No. 91947, posted 12 Feb 2019 09:25 UTC 
This is the Accepted Manuscript of an article published in Southern Economic Journal Vol. 55, No. 1, (July, 1988) available online: https://www.jstor.org/stable/1058864

\section{Foreign Subsidiary, Transfer Pricing and Tariffs*}

\section{CHANDER KANT}

Catholic University of America Washington, D.C.

\section{Introduction}

One of the truly distinguishing characteristics of multinational firms (MNFs) is the intra-firm transactions among units located in different countries. The MNF is not constrained by market forces in setting the terms, in particular, the transfer price, at which such transactions take place. Although the MNF literature frequently assumes $[12 ; 1 ; 25 ; 17]$ that the MNF faces government regulations, or a threat of a regulation, on its transfer price, most authors $[3 ; 20 ; 9 ; 19 ; 18 ; 21 ; 7$; 4] who have written on this subject have expressed doubts whether a legal policy (if it exists) on the transfer price can be effectively implemented. For example, Katrak [ 18, 509] states, "Bearing in mind the size and influence of some multi-national firms relative to that of some nation states, is it realistic to assume that a nation state can easily impose monopoly-regulation policies on multi-nationals? ... the literature on the subject has frequent references to the contrary."

Hood and Young [11] report that the percentage of less than wholly owned subsidiaries is large, and is increasing. Thus, for the U.S. based MNFs, the proportion of not wholly owned subsidiaries established increased from 42 percent in the period prior to 1951 to 56 percent in the years 1971-75; for Europe-based MNFs, it increased from 61 percent before 1951 to 81 percent during 1966-70; and for other MNFs it increased from 73 percent to 94 percent. Thus, the foreign subsidiaries are generally not wholly owned. The literature, however, has not analyzed transfer pricing in that situation.

The purpose of this paper is to examine the MNF's transfer pricing strategy when its subsidiary could be less than wholly owned. Lack of an effective regulation (or, its threat) on the transfer price is also assumed. Although the former can be introduced by a straightforward extension of the existing MNF models, it is found to have the dominant influence on the MNF's transfer pricing strategy; generally changing it from desiring a "low" transfer price (LTP) to wanting an "high" transfer price (HTP). We find that an HTP can increase the revenue of the host government while Metzler paradox (implying a fall in domestic price or output of the import good as a result of a tariff [22]) is not possible when domestic monopoly has its own affiliate as the foreign supplier. Further, and paradoxically, it is shown here that an increase in the tariff rate increases the transfer price (the foreign price of imports) if imports decrease substantially.

*I wish to thank Professor Josef Hadar and an anonymous referee for comments on an earlier draft of the paper However, I remain responsible for all remaining errors. 
The plan of the paper is as follows. We present the model and allow for less than wholly owned subsidiary in section II. Section III examines the determination of the profit-maximizing transfer price. In section IV maximization of the profit function with respect to sales and exports is investigated and effects of a tariff change are studied. Section V gives a summary of the main conclusions.

\section{Profit Function and Non-Wholly Owned Subsidiary}

Consider a MNF producing and selling a final good in two countries. It produces under increasing costs and cost/revenue considerations are such that it exports a part of its output from the parent firm in Country 1 (source or home country) to its affiliate in Country 2 (host or foreign country). An exchange rate of unity between the currencies of the two countries is assumed. Let $\pi_{i}, t_{i}, s_{i}, x_{i}, R_{i}\left(s_{i}\right), C_{i}\left(x_{i}\right), c_{i}, r_{i}^{\prime}$ and $c_{i}^{\prime}$ represent gross pure profits, aggregate profit tax rate, sales, production, total revenue and total cost (including normal profits) functions, marginal revenue, marginal cost, and slopes of marginal revenue and marginal cost functions in Country $i(i=1,2)$, and let $T_{i}=\left(1-t_{i}\right) .{ }^{1}$ The MNF faces imperfectly competitive markets in the two countries and price discrimination between the two countries is possible. Then,

$$
\pi_{1}=R_{1}\left(s_{1}\right)-C_{1}\left(s_{1}+m\right)+p m \text {, and } \pi_{2}=R_{2}\left(s_{2}\right)-C_{2}\left(s_{2}-m\right)-p(1+\tau) m \text {, }
$$

where $m$ are the MNF's imports from Country 1 to Country 2, $p$ is the transfer price, and $\tau$ is the "ad valorem" tariff on imports in Country 2. Clearly, $x_{1}=s_{1}+m$, and $x_{2}=s_{2}-m$.

The MNFs have ownership with control over the foreign affiliate. The control element is ensured if the parent firm has majority ownership over the foreign affiliate [19]. Let $k$ be the proportion of the parent firm's ownership in the foreign affiliate. Then, for a subsidiary $1 / 2<k \leq 1$, while for a branch, $k=1$.

The global net profit function, $\pi$, when less than complete ownership over the subsidiary is allowed, is now derived. In most source countries, the home country, while taxing the MNF's global gross profits, gives a tax credit for foreign taxes paid. ${ }^{2.3}$ The tax credit is, however, limited by the home tax on foreign profits. Thus, when

Case 1: $t_{1} \geq t_{2}$

The MNF pays $t_{2} k \pi_{2}$ as taxes to the foreign country and receives an equal tax credit. Thus,

$$
\pi=\left(\pi_{1}+k \pi_{2}\right)-t_{1}\left(\pi_{1}+k \pi_{2}\right)-t_{2} k \pi_{2}+t_{2} k \pi_{2}=T_{1}\left(\pi_{1}+k \pi_{2}\right) .
$$

It shall be assumed in this paper that $\left(\pi_{1}+k \pi_{2}\right)>0$ This rules out both simultaneous losses in the foreign branch and the parent firm, and loss in one of them so large that it makes the MNF's overall gross profits negative.

Case 2: $t_{1}<t_{2}$

Like Case 1 above the profit function is the same irrespective of whether the foreign affiliate is a branch or a subsidiary. The MNF pays $t_{2} k \pi_{2}$ in taxes to the foreign country but receives a tax credit of only $t_{1} k \pi_{2}$. Thus, 


$$
\pi=\left(\pi_{1}+k \pi_{2}\right)-t_{1}\left(\pi_{1}+k \pi_{2}\right)-t_{2} k \pi_{2}+t_{1} k \pi_{2}=T_{1} \pi_{1}+T_{2} k \pi_{2} .
$$

The forms of $\pi$ derived by Horst [14], and ltagaki [15; 16] are similar to (1), and (2) above, although they restrict their discussion to a branch or a fully owned subsidiary.

\section{Determination of the Transfer Price}

The MNF's choice problem is to choose $s_{1}, s_{2} m$ and $p$ so as to maximize $\pi$. This problem can most suitably be examined by following a two-stage maximization procedure: it first maximizes $\pi$ with respect to $p$ obtaining $p$ as a function of $s_{1}, s_{2}$ and $m$; it then substitutes this value of $p$ in its objective function and maximizes it with respect to $s_{1}, s_{2}$ and $m$. As will be shown shortly, there is a kink in the profit function (under certain conditions) when drawn against $p$, and $\pi_{P}$ does not exist at that point. Thus, the usual method of calculus is not suitable for maximizing $\pi$ with respect to $p$. Optimization for the two cases is presented below:

Case 1: $t_{1} \geq t_{2}$

The MNF faces (1) as its objective function, and

$$
\pi_{p}=m T_{1}[1-k(1+\tau)]
$$

Horst [13] and Eden [6] consider wholly-owned versions of (1), and conclude that in that case the MNF always chooses a LTP. Shifting profits to Country 2 through a LTP saves tariff payments. But, if the foreign-affiliate is not wholly owned, the profits shifted to Country 2 have to be shared with the foreign residents. Less than whole ownership over the subsidiary may thus make the MNF choose a completely different transfer pricing strategy from that when the subsidiary is wholly owned. Iff,

$$
k(l+\tau)<l,
$$

the MNF will shift profits to Country 1 rather than the other way round, i.e., an HTP would be desirable. As an extension, we examine how high a profitable transfer price is. Since an increase in $p$, with other variables constant, decreases $\pi_{2}$ (and increases $\pi_{l}$ ) monotonically, there exists a $p_{u}$ such that $\pi_{2}=0$ for $p=p_{u}$. For $p>p_{u}$ the MNF incurs losses in Country 2. But, as stated above, that does not give it any tax benefits in Country $l$ and $\pi$ declines. $\pi$ drawn against $p$ 


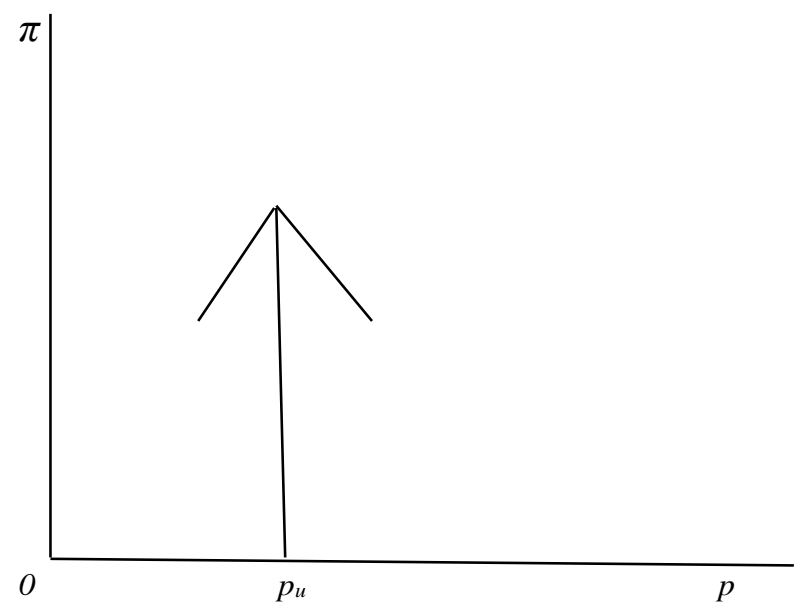

Figure 1. Possible Shape of the Profit Function.

looks like a roof and $p=p_{u}$ maximizes $\pi$. This is illustrated in Figure 1. Thus, a limit on how high a profitable transfer price is until profits in the subsidiary are zero. ${ }^{4}$

The value of $p_{u}$ can be obtained by solving the equation $\pi_{2}=0$ for $p$. Thus,

$$
p_{u}=\left[R_{2}\left(s_{2}\right)-C_{2}\left(s_{2}-m\right)\right](1+\tau) m
$$

A necessary condition for (4) is that $\tau<100 \%$ while a sufficient condition is that both $k$ and $\tau$ should not be high. Thus, we may state the following proposition:

PROPOSITION 1. When $t_{1}>t_{2}$, the foreign affiliate is not a wholly owned subsidiary, the tariff rate is less than $100 \%$, and both $k$ and $\tau$ are not high so that $k(1+\tau)<1$ holds, the MNF chooses an HTP, and its optimum transfer price is given by $(5) .^{5}$

The effects of transfer pricing on the host government's revenues are now examined. Let $V_{2}$ represent these revenues. Then,

$$
\begin{gathered}
V_{2}=t_{2} \pi_{2}+\tau p m, \\
\left(\partial V_{2} / \partial p\right)=m\left(1-t_{2}\right)\left[\tau-\left\{t_{2} /\left(1-t_{2}\right)\right\} \mid\right]
\end{gathered}
$$

Clearly, $\left(\partial V_{2} / \partial p\right)$ is unambiguously negative only if $\tau \leq 0$. In this paper, $\tau>0$ is assumed. Then, the effects of an HTP on Country 2's revenue depend on the relative magnitudes of $\tau$ and $t_{2}$. Increasing the transfer price decreases the importing country's profit tax revenue. But it increases its tariff revenue at the same time. The literature on this subject assumes that the importing country loses revenue by an HTP. But the precise effects of transfer pricing on the two countries' revenues when tariffs exist have not been examined. If the increase in tariff revenue is 
greater than the decrease in profit tax revenue, the importing country's overall revenue, in fact, increases with an HTP so that it would have no obvious reason to be concerned about an HTP. ${ }^{6}$

Case 2: $t_{1}<t_{2}$

The profit function now is given by (2). It can be shown with similar analysis that is this case, iff

$$
k(1+\tau)-1<\left(t_{2}-t_{1}\right) /\left(1-t_{2}\right)
$$

the optimum transfer price shall be $p_{u}$. It may be noted that the $k=1$ version of (2) is the most widely used profit function in the MNF literature $[12 ; 25 ; 6 ; 16]$. Using this profit function, the literature concludes that the MNF charges a LTP iff the tariff rate is greater than the relative tax differential, $\left(t_{2}-t_{1}\right) /\left(1-t_{2}\right)$. But, when $k<1, k(1+\tau)-1=(1+\tau)(k-1)+\tau<\tau$. Then, (8) may hold (and the MNF may charge an HTP) even if the tariff rate dominates over the relative tax differential. Thus, allowing for a less than wholly owned subsidiary may again make the MNF change its strategy from one of desiring a LTP to that of wanting an HTP. ${ }^{7}$

It can be seen that (4) is a sufficient, though not necessary, condition for (8). (4) gives $p_{u}$ as the optimum transfer price when $t_{1} \geq t_{2}$ while (8) gives the same solution for $t_{1}<t_{2}$. These two results can be combined and stated as:

PROPOSITION la. When the foreign affiliate is not a wholly owned subsidiary, the tariff rate is less than 100\%, and both $k$ and $\tau$ are not high, the MNF chooses an HTP, and its optimum transfer price is $p_{u}$.

The conditions for this proposition are fairly broad. Since a tariff rate of $100 \%$ or higher is generally not observable, the above proposition suggests that the dominant effect on the transfer price is likely to come from the extent of local shareholding in the subsidiary rather than from the tax rate differential and tariffs. Caves $[2,87]$ notes that joint ownership exacerbates the problems of pricing of intra-firm transactions. The above analysis reinforces such statements in the literature, and formally investigates, perhaps for the first time, the effects of less than whole ownership over the subsidiary on transfer pricing.

The profit-maximizing transfer price given by (5) is a negative function of the tariff rate while the operational profit in Country $2,\left(R_{2}-C_{2}\right)$, affects it positively. There is nothing in this model to relate $p_{u}$ to the efficient or shadow transfer price, $c_{1}$ [ 10]. If the operational profit in Country 2 is low and the tariff rate high, $p_{u}$ could be low and could equal $c_{1}$. In that case, marginal gain in Country I due to exports from there is zero. Global profitability of exports then implies (for both the cases discussed above) that imports in Country 2 provide marginal gains to the MNF, i.e., $\mathrm{p} \tau *<\mathrm{c}_{2}{ }^{8}$ At a "high" tariff rate, this last condition is likely to be satisfied if marginal cost of production in the importing country is also high. Thus, the profit-maximizing transfer price, $p_{u}$, on exports from Country 1 to Country 2 can equal the efficient transfer price, $\mathrm{c}_{1}$, if both the tariff rate and the marginal cost of production in Country 2 are high, and its operational profits there are low. 


\section{Optimum Levels of Sales and Exports and Effects of Tariffs}

Second stage of the maximization exercise is now performed in which the solution for the transfer price is substituted in $\pi$, and $\pi$ is optimized with respect to sales and exports. ${ }^{9}$ The solution, given by (5), makes $\pi_{2}=0$, and the MNF's global net profit function takes the form $\pi=T_{1} \pi_{1}$.

Substituting (5) in $\pi=T_{1} \pi_{l}$, we get

$$
\left.\pi=T_{1}\left\{R_{1}\left(s_{1}\right)-C_{1}\left(s_{1}+m\right)+\left[R_{2}\left(s_{2}\right)-C_{2}\left(s_{2}+m\right)\right] /(1+\tau)\right]\right\} .
$$

(9) shows that although $\pi$ at this stage equals $T_{l} \pi_{l}$, due to the substitution of $p=p_{u}$, it is a function of variables in both the countries.

Assuming the existence of an interior maximum, viz. $s_{1}>0, s_{2} \geq m>0$, the first order conditions yield

$$
\begin{aligned}
& (1+\tau)\left(r_{1}-c_{1}\right)=0, \\
& \left(r_{2}-c_{2}\right)=0, \\
& c_{2}-(1+\tau) c_{1}=0 .
\end{aligned}
$$

The second order conditions are derived in the Appendix, and are satisfied under the usual assumptions of declining marginal revenues and increasing marginal costs in the two countries so that the solution vector $\left(s_{1}, s_{2}, m\right)$ given by $(10)$ - (12) is indeed the unique maximum. ${ }^{10}$

The effects of changes in the tariff rate on $\mathrm{s}_{1}, m$, and $\mathrm{x}_{1}, i=1,2$, (derived in the Appendix) show that exports from Country 1 decrease even though, given increasing costs, its cost advantage increases; and the output in Country 2 increases. Let $p_{2}\left(s_{2}\right)$ represent the domestic price in Country 2. Then,

$$
d p_{2} / d \tau=\left(d p_{2}, / d s_{2}\right)+\left(d s_{2} / d \tau\right)>0
$$

(since the MNF faces downward sloping demand curves in both the countries). Thus, the Metzler paradox, implying a fall in the domestic price or output of the import good as a result of a tariff, is not possible in this model. This is in contrast to Finger [8] and Panagariya [23] who show, in partial and general equilibrium models, respectively, that Metzler paradox may arise in the presence of domestic monopoly. But they do not consider a multi-national monopoly, and assume that the domestic monopoly imports from unrelated parties. Thus, tariffs can be expected to have protective effect when domestic monopoly has its own affiliate as the foreign supplier.

The effect on the transfer price is derived below:

$$
d p_{u} / d \tau=\left(c_{2} / \tau^{*} m\right)(d m / d \tau)-\left(p_{u} / \tau^{*}\right)\left[\left(\tau^{*} / m\right) \cdot(d m / d \tau)+1\right] .
$$

But, 


$$
d m / d \tau=\left(d m / d \tau^{*}\right)\left(d \tau^{*} / d \tau\right)=d m / d \tau^{*}
$$

so that,

$$
d p_{u} / d \tau=\left(c_{2} / \tau^{*} m\right)(d m / d \tau)-\left(p_{u} / \tau^{*}\right)\left[E_{m} \tau^{*}+1\right],
$$

where $E_{m} \tau^{*}=\left(\tau^{*} / m\right) .\left(d m / d \tau^{*}\right)<0$ is the elasticity of imports with respect to tariffs. Clearly, $d p_{u} / d \tau>0$ if $E_{m \tau}{ }^{*}<-1$.

In the exogenous transfer price models, marginal changes in the tariff rate have no effect on the transfer price since given the tax rate differential and tariffs, the MNF would always be charging the highest or the lowest values permitted by the tax and custom authorities. In Samuelson [25] and Eden [6] these limiting values are functions of the MNF's decision variables. Then, as expected, the MNF changes its decision variables in such a way that its transfer price decreases with a tariff increase. In this paper, however, an increase in the tariff rate does not assure a country a decrease in the transfer price: if imports are elastic with respect to tariffs, the transfer price may rise. The different results arise because here the transfer price maximizes the MNF's net global profits rather than simply satisfy an exogenously given rule.

One implication of the above result may be noted. The transfer price is the foreign price of imports to the importing country. We find this can increase especially when the quantity of imports decreases substantially. Thus, the normal price-quantity relationship cannot always be expected to hold for foreign supply when a large part of a country's trade is intra-firm. Some other results are: the host country satisfies the definition of a "large" country since it can affect the foreign price of imports. But even if the transfer price increases, the import bill, pm, decreases unambiguously, and the balance of trade of the host country improves. This is shown below:

$$
d\left(p_{u} m\right) / d \tau=\left(c_{2} / \tau^{*}\right)(d m / d \tau)-\left(p_{u} / \tau^{*}\right)<0 .
$$

Thus, the MNF's tariff payments tend to decrease. Eden [5] had suggested that when the transfer price cannot be changed a decrease in imports acts as a substitute for decreasing the transfer price. We show that it can act as a substitute even when the transfer price can be changed.

\section{Concluding Remarks}

In the transfer pricing literature, Horst [12] concludes that the MNF will generally charge a "low" transfer price while other authors are ambivalent on this question. This paper shows that less than whole ownership over the subsidiary generally makes the MNF change its transfer pricing strategy: from desiring a LTP to wanting an HTP. The conditions for an HTP are fairly broad so that we are more likely to observe it than has been suggested in the literature. The MNF literature also presumes that the host country loses revenue due to an HTP. However, this view ignores the effects of tariffs on a government's revenue. If tariff revenue is included an HTP can increase the host country's revenue. 
Finger [8] and Panagariya [23] conclude that the Metzler paradox is possible in the presence of domestic monopoly. But they do not consider a multinational monopoly. We show that the Metzler paradox is not possible when domestic monopoly has its own affiliate as the foreign supplier. Further, it is shown here that the foreign price of imports (the transfer price) may increase with tariffs if imports decrease substantially. Thus, the normal price quantity relationship cannot be assumed for foreign supply when a large part of a country's trade is intrafirm.

\section{Appendix}

Taking the total derivatives of the first order equations (10) - (12) with respect to $\tau$, we get

$$
\left[\begin{array}{ccc}
\tau^{*}\left(r_{1}^{\prime}-c_{1}\right) & 0 & -\tau^{*} c_{1}^{\prime} \\
0 & \left(r_{2}^{\prime}-c_{2}^{\prime}\right) & c_{2}^{\prime} \\
-\tau^{*} c^{\prime}{ }_{1} & c_{2}^{\prime} & -\left(c_{2}^{\prime}+\tau^{*} c^{\prime}{ }_{1}\right)
\end{array}\right]\left[\begin{array}{l}
d s_{1} / d \tau \\
d s_{2} / d \tau \\
d m / d \tau
\end{array}\right]=\left[\begin{array}{l}
0 \\
0 \\
c_{1}
\end{array}\right]
$$

Let $D$ represent the determinant of the above coefficient matrix. Then, in view of the assumptions made in the text, $D$ and the elements on its principal diagonal are all negative and its second principal minor is positive. The second order conditions are thus satisfied. Solving by Cramer's rule, we have

$$
\begin{aligned}
& d s_{1} / d \tau=\tau^{*} c_{1} c_{1}^{\prime}\left(r_{2}^{\prime}-c_{2}^{\prime}\right) / D>0 \\
& d s_{2} / d \tau=-\tau^{*} c_{1} c_{2}\left(r_{1}^{\prime}-c_{1}^{\prime}\right) / D<0
\end{aligned}
$$

and

$$
d m / d \tau=\tau^{*} c_{1}\left(r_{1}^{\prime}-c_{1}^{\prime}\right)\left(r_{2}^{\prime}-c_{2}^{\prime}\right) / D<0
$$

Similarly,

$$
d x_{1} / d \tau=\left(d s_{1} / d \tau\right)+(d m / d \tau)=\tau^{*} c_{1} r_{1}^{\prime}\left(r_{2}^{\prime}-c_{2}^{\prime}\right) / D<0
$$

and

$$
d x_{2} / d \tau=\left(d s_{2} / d \tau\right)-(d m / d \tau)=-\tau^{*} c_{1} r_{2}^{\prime}\left(r_{1}^{\prime}-c_{1}^{\prime}\right) / D>0
$$




\section{References}

1. Batra, Raveendra N. and Josef Hadar, "Theory of the Multinational Firm: Fixed Versus Floating Exchange Rates." Oxford Economic Papers, July 1979, 258-69.

2. Caves, Richard E. Multinational Enterprise and Economic Analysis. Cambridge: Cambridge University, 1982.

3. Copithorne, Lawrence W., "International Corporate Transfer Prices and Government Policy." The Canadian Journal of Economics, August 1971 , 324-41

4. Diewert, W. Erwin. "Transfer Pricing and Economic Efficiency", in Multinationals and Transfer Pricing, edited by A. M. Rugman and L. Eden. New York: St. Martin's, 1985.

5. $\quad$ Eden, Lorraine, "Vertically Integrated Multinationals: A Micro-economic Analysis." The Canadian Journal of Economics, August 1978, 534-46.

6. __ _ _ "Transfer Pricing Policies under Tariff Barriers " The Canadian Journal of Economics, November 1983, 669-85.

$7 . \quad$ _ . "The Microeconomics of Transfer Pricing," in Multinationals and Transfer Pricing, edited by A M Rugman and L. Eden. New York. St. Martin's, 1985.

8. Finger, J. M., "Protection and Domestic Output." Journal of International Economics, August 1971, 345-51.

9. Hanson, James S., "Transfer pricing in the Multinational Corporation: A Critical Appraisal " World Development, November/December 1975, 857-65

10. Hirshleifer, Jack, "On the Economics of Transfer Pricing." Journal of Business, November 1956, 172-84.

11. Hood, Neil and Stephen Young. The Economics of Multinational Enterprise New York. Longman, 1979.

12. Horst, Thomas, "The Theory of the Multinational Firm: Optimal Behavior under Different Tariff and Tax Rates." Journal of Political Economy, September/October 1971, 105972.

13. _ _ "The Simple Analytics of Multinational Firm Behavior," in international Trade and Money, edited by Michael B. Connolly and Alexander K. Swoboda. London: George Allen and Unwin, 1973, pp 72-84.

14. , "American Taxation of Multinational Firms." American Economic Review, June 1977, 376-89.

15. Itagaki, Takao, "Theory of the Multinational Firm: An Analysis of Effects of Government Policies." International Economic Review , June 1979, 437-48. 
16. "Systems of Taxation of Multinational Firms under Exchange Risk." Southern Economic Journal , January 1982, 708-23

17. Kant, Chander, "Endogenous Transfer Pricing and the Effects of Uncertain Regulation." Journal of International Economics, forthcoming

18. Katrak, Homi, "Multinational Monopolies and Commercial Policy· A Qualification and a Reply," Oxford Economic Papers, October 1979, 508-11 .

19. Kopits, George K., "Taxation and Multinational Firm Behaviour: A Critical Survey." I. M . F. Staff Papers, November 1976, 624-73.

20. Lall, SanJaya, "Transfer Pricing by Multinational Manufacturing Firms." Oxford Bulletin of Economics and Statistics, August 1973, 173 - 95.

21. Lessard, Donald R. "Transfer Prices, Taxes and Financial Markets: Implications of International Financial Transfers Within the Multinational Corporation," in Research in International Business and Finance: The Economic Effects of Multinational Corporations, edited by R. G. Hawkins. Greenwich, Connecticut. JAI Press, Inc., 1979, pp. 101-25.

22. Metzler, Lloyd A , "Tariffs, the Terms of Trade and the Distribution of National Income." Journal of Political Economy, February 1949, 1-29.

23. Panagariya, Arvind, "Tariff Policy under Monopoly m General Equilibrium." International Economic Review, February 1982, 143-56.

24. Rugman, Alan M., Inside the Multinationals. The Economics of Internal Markets. London and New York: Croom Helm and Columbia University Press, 1981.

25. Samuelson, Larry, "The Multinational Firm with Arm's Length Transfer Price Limits." Journal of International Economics, November 1982, 365-74.

\section{Endnotes}

1. Aggregate profit tax rate here means the profit tax rate plus the withholding tax on dividends. We assume that capital cost recovery allowances, other deductions or exemptions, and reduced tax rates or outright subsidies granted for particular activities or regions $m$ most tax codes make the taxable profits approximately equal to pure profits so that the statutory profit tax is levied and realized on pure profits.

2. The difference in tax treatment at home of income of a foreign branch from that of a foreign subsidiary may be noted. When it is a branch, it is treated as a legal extension of the parent firm, and Its income, whether positive or negative, is immediately recognized by the home country just like the income of the parent firm. On the other hand, when it is a subsidiary, which is incorporated in a foreign country under the foreign country's law, its profits are taxed in the home country only upon repatriation. Its losses, on the other hand, cannot be repatriated to the home country. The MNF thus does not gain any tax advantage $\mathrm{m}$ the home country by showing losses in the foreign subsidiary, and could always raise its $\pi$ by closing down such a subsidiary, $i$ e., $\pi_{2} \geq 0$. 
3. Absence of any loss carry-forward or carry-backward provisions is assumed, or, the period may be considered long-enough for any carry-over to be exhausted. Similarly, we assume that when the subsidiary earns positive profits, their repatriation is either not deferred, or, the period is considered long-enough for repatriation to take place.

4. Although this meaning of the HTP may not be new, the MNF literature has not pursued this point. We work through the results on the assumption that a transfer price regulation either does not exist, or, if it exists, is so ineffective that the MNF ignores it. In addition, we show below that the host country's revenue. for example, may increase with an HTP so that it will have no obvious reason to impose a transfer price regulation.

5. When (4) is not met, the MNF chooses a LTP and an endogenous solution to Its optimizing problem does not exist. In what follows, we shall emphasize the conditions under which endogenous solutions of the transfer price are obtained. Also $\pi_{p} \neq 0$ shall be assumed.

6. It may be noted that the local shareholders in Country 2 earn positive pure profits when $\pi_{2}>0$, and normal profits when $\pi_{2}=0$. Even in the latter case, if they do not have any other equally secure investment giving a significantly higher return, they would also be in equilibrium (since they would be earning the opportunity cost of their capital). We assume that they are far too diffused and lack information to demand that the parent-firm always shares some of its pure profits with them.

7. Similarly, when the relative tax differential overrides the tariff, the introduction of a not wholly owned subsidiary will provide it an even greater incentive to charge an HTP since in that case $k(1+\tau)-1<\tau<\left(t_{2}-t_{1}\right) /\left(1-t_{2}\right)$

8. The derivative of the profit function (1) with respect to $m$ is, $\pi_{m}=T_{1}\left[\left(p-c_{1}\right)+k\left(c_{2}\right.\right.$ $\left.\left.p \tau^{*}\right)\right]$. When $\left(p-c_{1}\right)=0, \pi_{\mathrm{m}}>0$ implies $\left(c_{2}-p \tau^{*}\right)>0$. A similar conclusion can be drawn for the other profit function. In that case, marginal imports in Country 2 save more in production costs (by displacing production in that country) than add to import costs, i. e., they increase profits $\mathrm{m}$ Country 2. Although. given the parameter values, the MNF is interested in shifting profits out of Country 2 , 1t does not achieve it by curtailing its profit-enhancing intra-firm trade but attains it by adjusting its transfer price.

9. The following discussion is applicable only for situations for which we were able to obtain a determinate transfer price.

10. It may be noted from (10) - (12) that the tax rates do not affect the decision variables although the profit function (9) Is a function of variables in both the countries It has been suggested in the internalizing literature [24) that transfer pricing counteracts exogenous market imperfections like differential taxes and tariffs. This paper supports internalizing literature as far as differential taxes are concerned. When the MNF can freely respond to differential taxes and tariffs, it chooses a transfer price that makes marginal changes in the tax rates irrelevant. This suggests that the non-neutral tax effects derived by Itagaki [15), Samuelson [25), and Eden [7) 
could be more due to the fact that the MNF, in their models, is restricted in its choice of the profit-max1m1zing transfer price rather than to it being a "multinational" firm. 